\title{
OBITUARY
}

\section{Dr. Muhammad Jamil Akhtar}

(November 2, 1959 - November 19, 2021)

\section{A memoir from his family}

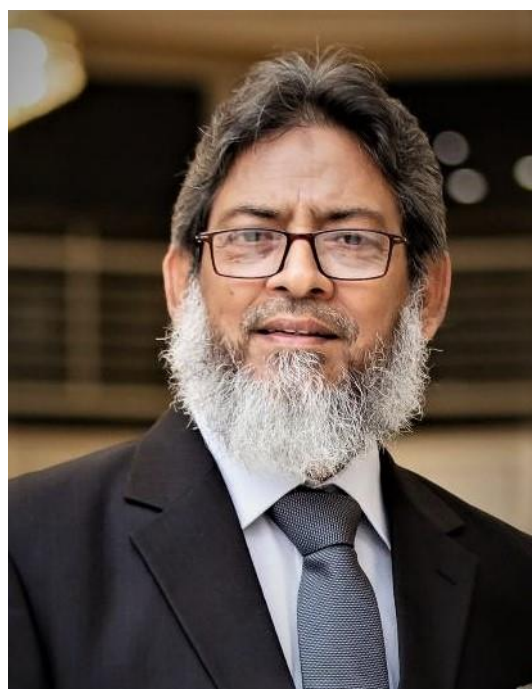

Dr. Muhammad Jamil Akhtar was born on November 2, 1959, in East Pakistan (now Bangladesh). He received his early education there, then migrated to Pakistan when he was merely 13 years old.

He was a bright and intelligent student and worked very hard to achieve his career aspirations. He did his matriculation with distinction in all subjects, completed his intermediate from DJ Science college and then enrolled in Dow University of Health Sciences. He went on to complete his MCPS in 1986 and FCPS in 2002.

Dr. Jamil was known as one of the best anesthesiologists in the medical fraternity. He practiced and taught in AKUH, Civil Hospital, and Imam Clinic. Dearest to his heart, however, was his personal practice and clinic to which he dedicated 31 years of his life, serving people like a true Messiah. He was a mentor, a Guru who taught and trained many under his wing.

He was a gifted conversationalist and had an uncanny ability to touch people deeply - young and old alike, enjoyed his lively conversations and discussions. His wisdom made him a great advisor, counselor, and confidante. What many don't know about him was his strong bond with religion. He had profound love for Holy Prophet (PBUH) and enjoyed reading about His life and embody it in his own.

His sudden passing away made us realize that not only we lost a father and husband, but the world lost a great human. He built meaningful relationships with everyone around him, especially his patients, and that resonates in one of the many condolence messages we received that is worth mentioning. He will always be loved, and his warm smile, comforting hugs and sparkling eyes forever remembered.

\section{Asma Jamil}

Daughter of Dr. Muhammad Jamil Akhtar

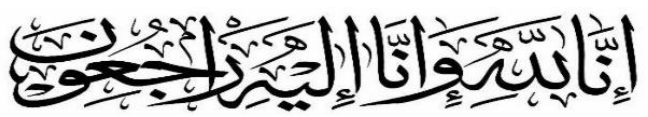

